\begin{tabular}{|l|l|l|l|l|l|}
\hline MUNIBE Antropologia-Arkeologia & $n^{\circ} 71$ & $41-57$ & DONOSTIA & 2020 & ISSN 1132-2217 • elSSN 2172-4555 \\
\hline
\end{tabular}

\title{
New archaeological data on the Upper Paleolithic site of cueva de Malalmuerzo (Moclín, Granada, Spain)
}

\author{
Nuevos datos arqueológicos del Paleolítico superior en la cueva \\ de Malalmuerzo (Moclín, Granada, España)
}

KEY WORDS: Iberian Peninsula, Solutrean, Magdalenian, Rock art.

PALABRAS CLAVES: Península Iberica, Solutrense, Magdaleniense, Arte parietal.

GAKO-HITZAK: Iberiar penintsula, Solutre aldia, Madeleine aldia, horma-artea.

\author{
Lidia CABELLO(1,9), Pedro CANTALEJO ${ }^{(1)}, M^{a}$ de Mar ESPEJO(1), Antonio F. BUENDÍA ${ }^{(2)}$ \\ José M. FERNÁNDEZ(3), Manuel GONZÁLEZ RíOS ${ }^{(3)}$, Olga GONZÁLEZ ${ }^{(4)}$, Juan José DURÁN(5) \\ Pedro ROBLEDO(5), Bárbara AVEZUELA(6), Jesús F. JORDÁ PARDO(6,13), Paloma UZQUIANO ${ }^{(6)}$ \\ José A. RIQUELME ${ }^{(7)}$, Blanca RUIZ-ZAPATA(8), María J. GIL-GARCíA(8), José RAMOS MUÑOZ ${ }^{(9)}$ \\ Gerd-Christian WENIGER ${ }^{(10)}$, Alfonso PALOMO ${ }^{(11)}$, Víctor Manuel SMITH ${ }^{(11)}$, Serafín BECERRA ${ }^{(9)}$ \\ Diego SALVADOR FERNÁNDEZ ${ }^{(9)}$, Salvador DOMINGUEZ-BELLA ${ }^{(9)}$ \\ Yvonne TAFELMAIER ${ }^{(12)}$, Eduardo VIJANDE-VILA ${ }^{(9)}$
}

\section{ABSTRACT}

The Malalmuerzo cave (Moclín, Granada, Spain) has been known since the 1980s for its archaeological remains and rock art, dated to the Neolithic and the Solutrean periods respectively. However, following thirty years of neglect, our team carried out a brief archaeological intervention after looters destroyed parts of the sediment fill of the cave. The refreshing of disturbed surfaces and the examination of a small undisturbed profile produced many archaeological remains attributed to several Magdalenian levels. The levels partially covered the depiction of a red horse, which probably dates to the Solutrean period.

\section{RESUMEN}

La cueva de Malalmuerzo (Moclín, Granada, España) es conocida desde los años 80, del siglo pasado, por albergar restos arqueológicos del Neolítico y arte rupestre Solutrense. Sin embargo, tras treinta años de abandono, nuestro equipo llevó a cabo una intervención de urgencia después de la destrucción a manos de expoliadores de parte del sedimento arqueológico. La regularización y limpieza del perfil aportó gran cantidad de restos adscritos al Magdaleniense. Además se documentó la figura de un équido en rojo solutrense, cuya parte inferior estuvo parcialmente cubierta por el sedimento arqueológico objeto de nuestro estudio.

\section{LABURPENA}

Malalmuerzoko kobazuloa (Moclín, Granada, Espainia) joan den mendeko 80ko hamarkadatik da ezaguna Neolitikoko aztarna arkeologikoak eta Solutre aldiko labar-artea biltzen dituelako. Baina hogeita hamar urtez abandonatuta egon ondoren, gure taldeak urgentziazko esku-hartzea egin behar izan zuen espoliatzaile batzuek sedimentu arkeologikoaren zati bat suntsitu ostean. Profilaren garbiketari eta erregularizazioari esker, Madeleine aldiari atxikitako aztarna ugari topatu genituen. Gainera, Solutre aldiko ekido gorri baten irudia dokumentatu zuten. Haren beheko zatia gure ikerlanaren helburu izan den sedimentu arkeologikoarekin estalita egon zen partzialki.

\footnotetext{
(1) Cave of Ardales. Av. de Málaga, 1, 29550 Ardales, Málaga. lidia_cabelloligero@hotmail.com.

(2) Archaeologist

(3) Spanish School of Speleology

(4) Engineer

(5) Geological and Mining Institute of Spain

(6) National University of Distance Education

(7) University of de Córdoba

(8) University of Alcalá de Henares

(9) Group HUM-440 University of Cádiz

(10) Neanderthal Museum Mettmann

(11) University of Málaga

(12) State Office for Cultural Heritage Baden-Wuerttemberg / University of Tuebingen / Germany

(13) Group PREHUSAL University of Salamanca.
} 


\section{INTRODUCTION}

The Malalmuerzo cave is located in the municipality of Moclín, in the district of Montes Orientales, approximately $35 \mathrm{~km}$ from the city centre. It is situated northwest of Granada, east of the Peñón de Malalmuerzo, and south of Barranco del Lizán, which is situated $820 \mathrm{~m}$ a.s.l, and at a distance of $100 \mathrm{~km}$ from the coast (Fig. 1). It falls in Middle Sub-Baetic (Parapanda-Moclín Unit), the highest unit in the Sub-Baetic range. The cave is part of an endokarstic system of complex origin.

The cave was discovered in 1979 during an archaeological survey undertaken by Francisco Contreras and Francisco Carrión (University of Granada) (Carrión and Contreras, 1979). In the summer of 1983, the discoverers (Carrión and Contreras, 1983) undertook further excavations and confirmed the existence of archaeological remains dated to the Neolithic. Two groups of speleologists from Granada and Malaga also collaborated in the exploration of the cave, and during the topographic survey of the inner galleries they discovered a number of pieces of rock art that, based on stylistic criteria, were attributed to the Solutrean period (Cantalejo, 1983) (Fig. 2).
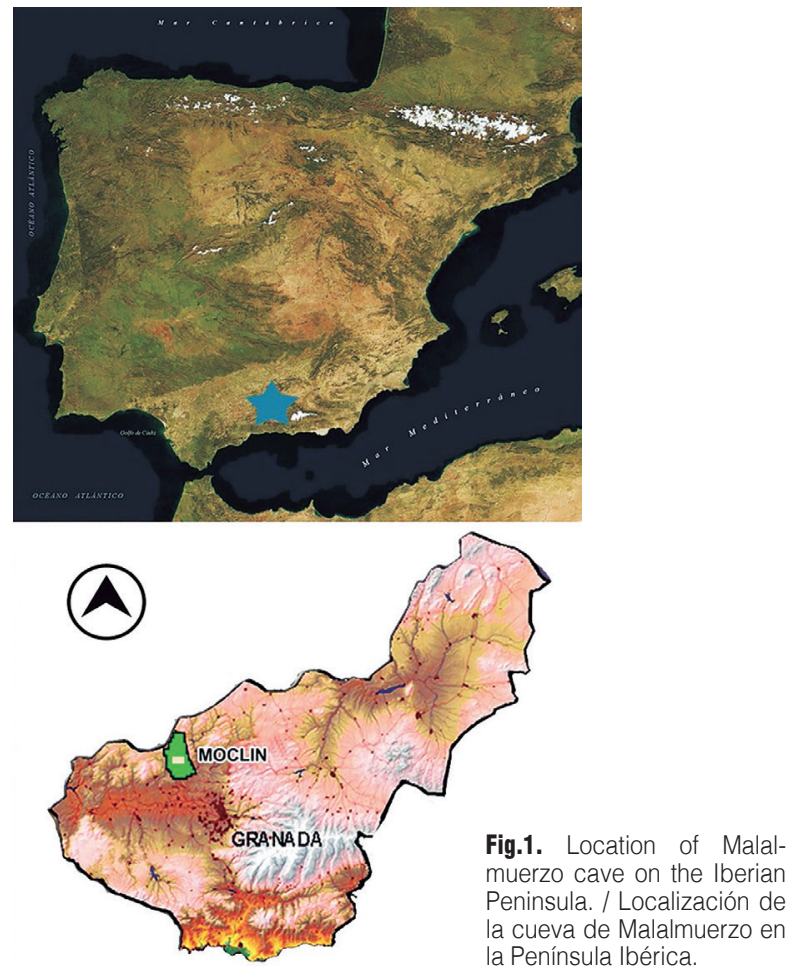

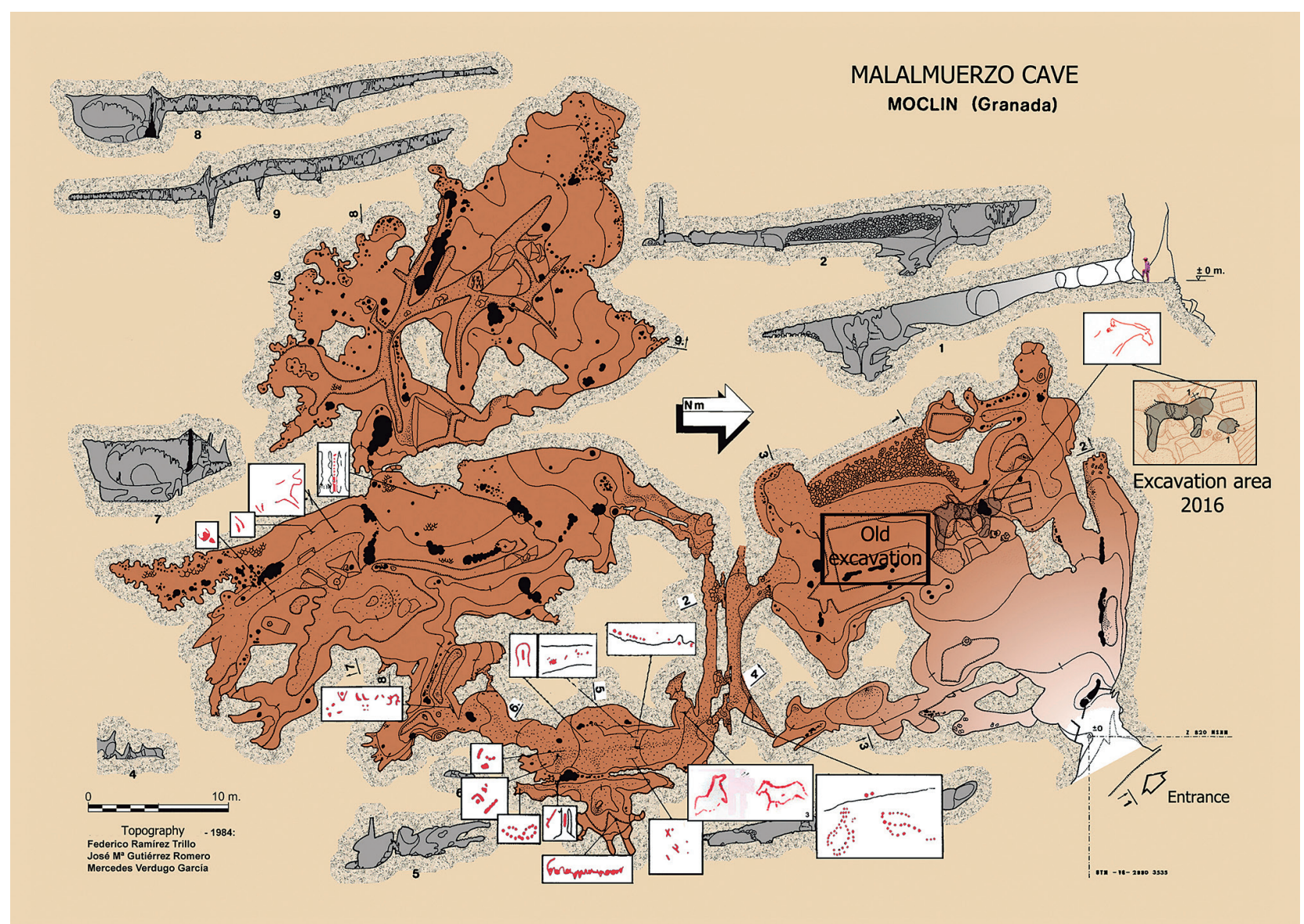

Fig.2. Topographic plan of Malalmuerzo cave showing excavation areas and distribution of rock art. / Topografía de la cueva de Malalmuerzo con las áreas de excavación y la distribución del Arte rupestre. 
Eventually, the regional government of Andalusia declared this cave Heritage of Cultural Interest in 1985. From that moment on, a number of researchers from the University of Granada have analysed the Neolithic occupation of the cave from an archaeological and anthropological perspective (Jiménez et al. 1986; Carrión and Contreras, 1983; Solari et al. 2012), confirming that the cave was visited by humans in the Upper Palaeolithic and the Neolithic.

In 2015, Antonio Buendía undertook a topographic re-examination of the cave (González Ríos, 2016), during which evidence for serious looting was observed in the narrow gallery of the first hall, where a concentration of red paintings was detected, partially covered by sediments containing archaeological finds (Fig. 3). As a result, in 2016 the provincial authorities, on the initiative of Antonio Montufo, asked our research team to begin an archaeological emergency intervention. The aim was to collect disturbed surface material, to refresh exposed surfaces and examine a small undisturbed profile. The results from the refreshing of the profile (1 $\mathrm{m} \times 0.6 \mathrm{~m}$ ) and the analysis of the associated remains are presented here. Despite the small size of the area under examination, numerous finds were collected. Anthropological and faunal remains, lithic artefacts, ochre and charcoal, among other finds, were recovered and analyzed. In addition, new radiocarbon dates were obtained from charcoal samples.

\section{EXCAVATION AND STRATIGRAPHY}

The cleaning of the archaeological section was carried out inside a niche accessible from the main hall of the cave; the area was referred to as MALM 16 Sector A. In addition, we also collected from the surface of the niche and in the entrance area, stone artefacts, bones, ornaments and pendants found in secondary position, caused by the anthropic alterations of looters inside the niche. These areas were referred referred to as MALM 16 SUP.2.1 and MALM 16 SUP. EXT. 7. All the data and results presented here correspond to the profile excavation (Fig. 4).

The archaeological excavation was limited to an extension of $1 \times 0.6 \mathrm{~m}$ in size. A fixed metal frame was installed to guide the excavation, facilitating the work and ensuring that all archaeological finds and samples were precisely located. To a large extent, the sediment consisted of an accumulation of heavily cemented small and medium sized debris fragments, including lithic artefacts, bones and charcoal, which formed solid crusts from bottom to top. In the areas where the crusts where particularly hard a small hammer and chisels had to be used.

The extracted sediments were water-sieved, dried and sorted into different find categories, such as faunal remains, lithic artefacts, charcoal, and ochre. After sorting, the archaeological finds were analysed by the

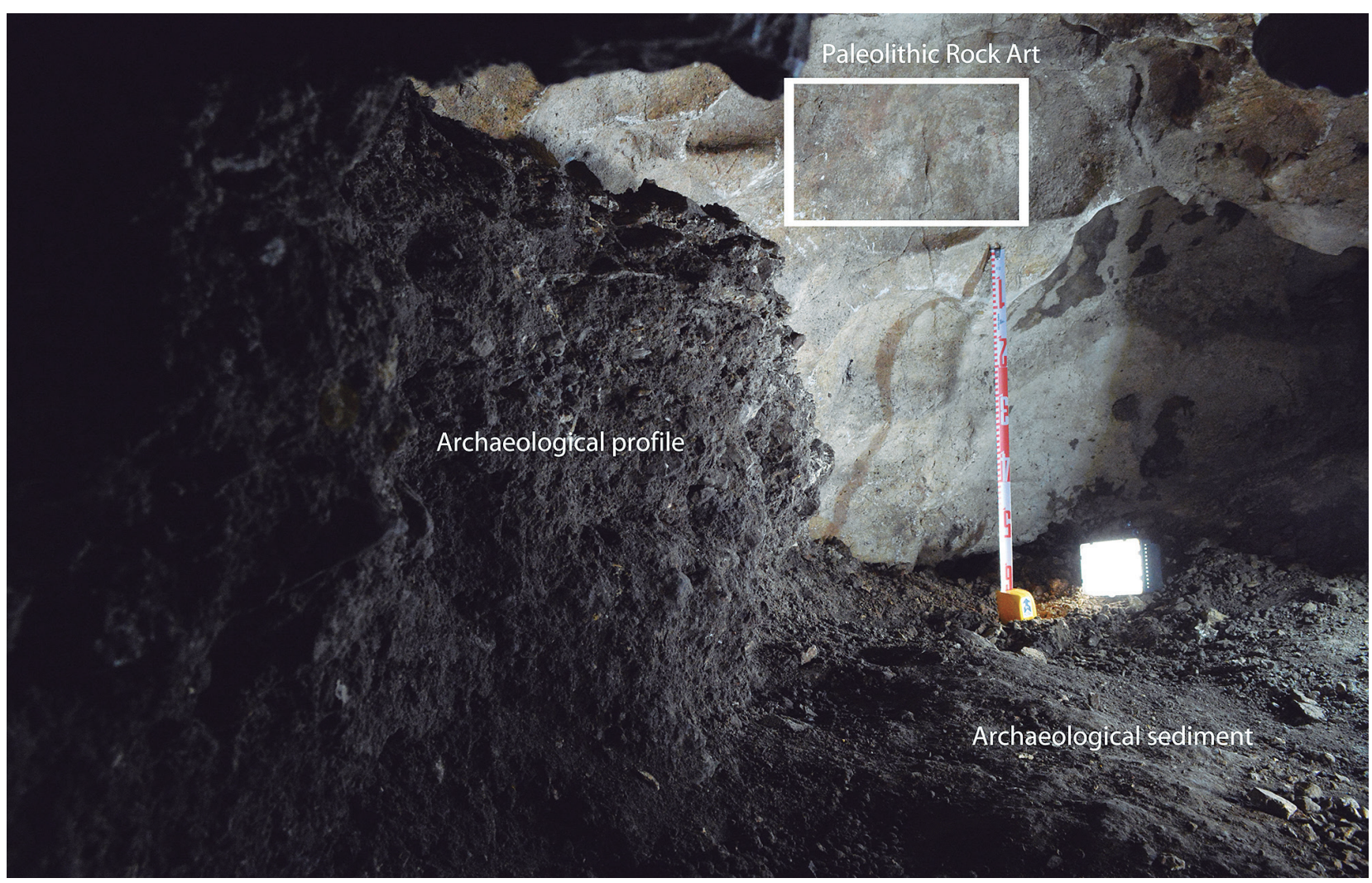

Fig.3. Archaeological profile and red paintings. / Perfil arqueológico y Arte paleolítico. 


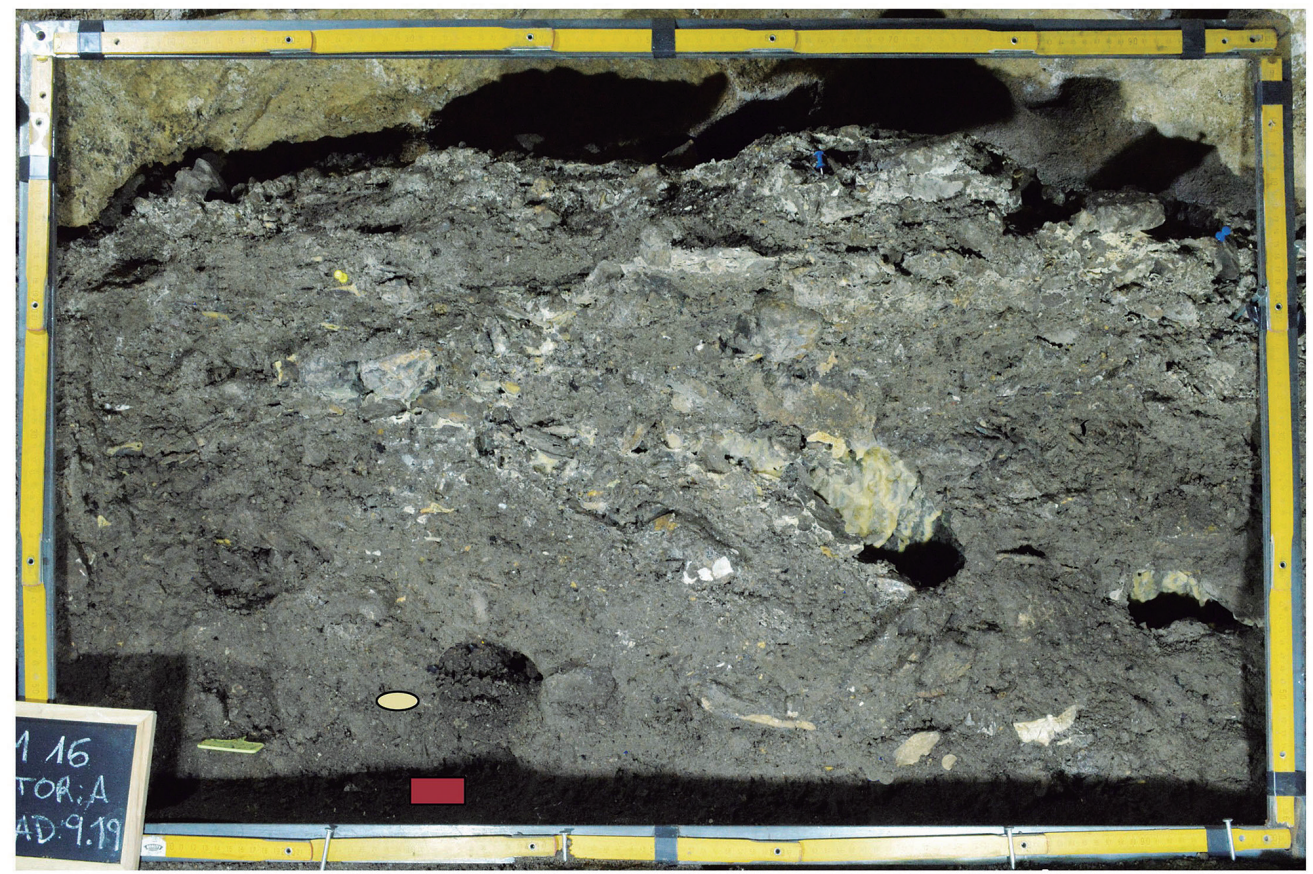

FINAL PHOTO MALM 16 SECTOR A

pestle of sandstone

plaquette with red spots

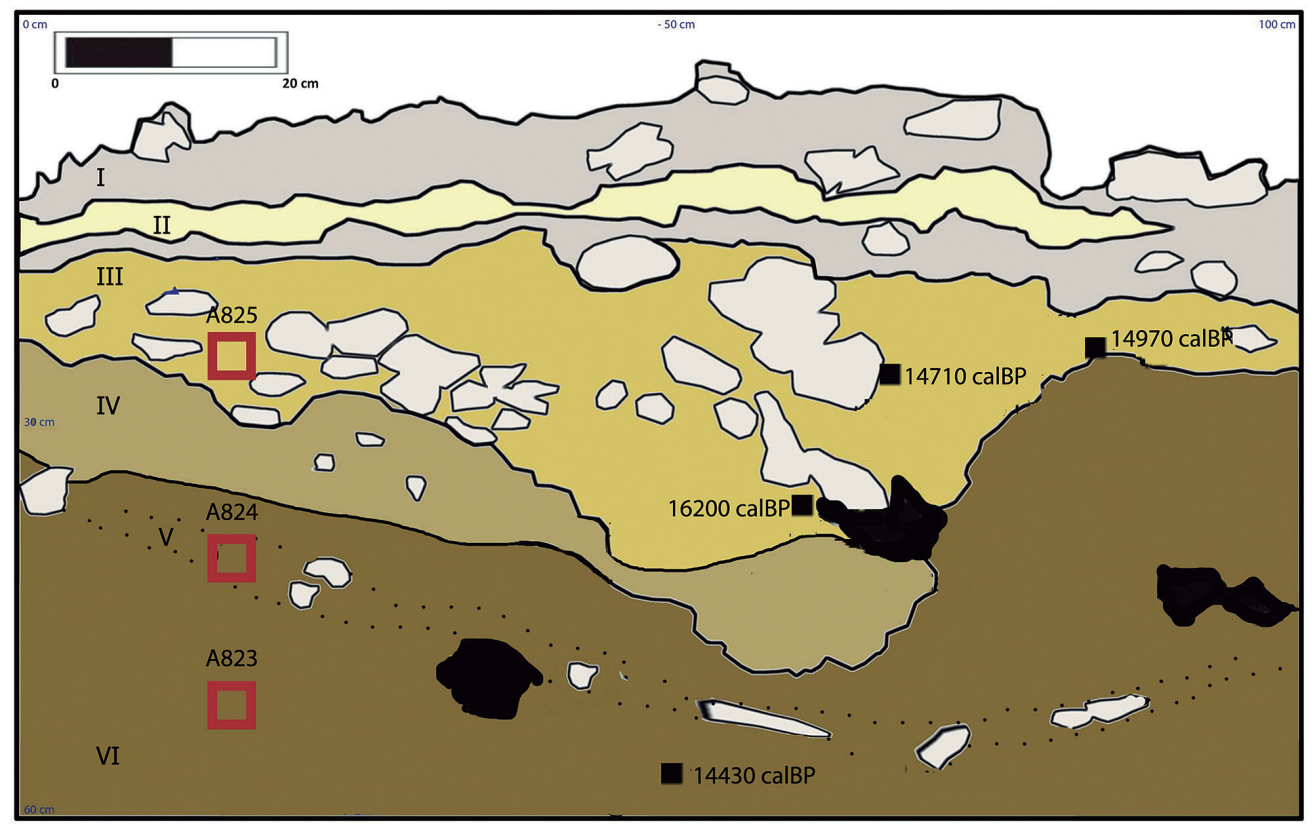

Fig.4. Archaeological levels identified during the excavation. Results of AMS dating (black squares) and sample for palynological analysis (red squares). / Niveles arqueológicos identificados durante la excavación. Resultados AMS (cuadros negros) y muestras para análisis palinológico (cuadros rojos)

FINAL ARCHAEOLOGICAL LEVELS MALM 16 SECTOR A.

specialists and the laboratories working with the Malalmuerzo research team.

Nine $2 \mathrm{~cm}$-spits were excavated, in the visible stratigraphic section comprising a total thickness of 18 $\mathrm{cm}$. This allowed for an exact location of all finds and samples.

On the other hand, although bedrock has not yet been reached, a sequence comprising six archaeological levels was documented (Fig. 4 and Tab. 1).
In broad outline, this sequence can be divided into two main lithostratigraphic units. The lower unit, which consists of three units (MALM.6, MALM.5 and MALM.4), is characterized by the presence of silts and brown clays with multiple intrusions in the form of clasts and small blocks. This are clearly identified as debris resulting from the detachment of rock fragments from outside the niche, also observed at units MALM.3. The upper lithostratigraphic unit, which includes other three units (MALM.3, MALM.2 and MALM.1), is composed by 
carbonate-cemented clasts resulting in brecciated deposits interspersed with levels of finer material.

At the bottom of MALM.4, cavities resulting from post-depositional dissolution processes were identified.

The archaeological sequence consists on the six lithostratigraphic units described above, but it must be taken into account that unit MALM.1 is divided into two sub-units. Lithic artefacts were found in all archaeological levels, most notably in levels 3 and 4, in which abundant faunal remains, charcoal and ochre, in some parts heavily cemented, were also identified. Level 3 yielded a series of flakes, points, blades and bladelets produced by pressure-flaking (Alix et al. 1995; Martín Lerma, 2015), as well as a small number of cores, micro debitage and chunks.

Archaeological levels 4 and 6 were separated by an archaeologically barren level, level 5, mainly composed of pebbles. Archaeological level 6 revealed a major concentration of lithic remains, as well as abundant charcoal fragments and a sandstone block identified as a plaquette, which was partly covered with ochre.

\section{MATERIAL, METHODS AND RESULTS}

\subsection{Radiocarbon dating}

The Pleistocene chronology is based on four Accelerator Mass Spectometry (AMS) radiocarbon dates on charcoal samples. Three charcoal fragments were selected from level 3 and one from level 6. All samples were measured the Cologne AMS Laboratory. Dating results are presented in Table 2 and indicate that the occupations of MALM 16 SECTOR A from level 3 to 6 can be dated to the Magdalenian. Three dates from level 3 are in good stratigraphic order. But the fourth date from the bottom of level 6 is the youngest. No evidence for bioturbation could be detected during the excavation.

The inverted stratigraphy could be due to postsedimentary processes within the niche. This charcoal sample could have been mobilized by water infiltration through empty spaces in the sediment. In Figure 4 these appear marked in black.

\begin{tabular}{|c|c|c|c|}
\hline $\begin{array}{l}\text { Lithostratigraphic } \\
\text { units }\end{array}$ & $\begin{array}{c}\text { Archaeological } \\
\text { levels }\end{array}$ & Thickness & Description \\
\hline MALM.6 & 6 & $10-20 \mathrm{CM}$ & $\begin{array}{l}\text { Basal level known so far formed by silts and dark brown clays, with coarse sands and limestone } \\
\text { gravel, somewhat rounded (quantile } 1 \mathrm{~cm} \text {, average } 2 \mathrm{~mm} \text { ). Contains remains of carbonized organic } \\
\text { matter as well as small bone fragments. The top contact appears strongly inclined towards the N, } \\
\text { marked by the disposition of the next level of clasts. }\end{array}$ \\
\hline MALM.5 & 5 & $5 \mathrm{CM}$ & $\begin{array}{l}\text { Accumulation of flat pebbles and plaquettes of white limestone (quantile } 12 \mathrm{~cm} \text {, average } 7 \mathrm{~cm} \text { ) } \\
\text { irregularly arranged in a single row. Its matrix is the material of MALM. } 6 \text {. Its disposition is confined to } \\
\text { the depositional surface, with a marked slope towards the } N \text { of the section. }\end{array}$ \\
\hline MALM.4 & 4 & $8-14 \mathrm{CM}$ & $\begin{array}{l}\text { Dark brown clayey silts but lighter than MALM.6, with thick coarse sands and fine limestone gravel, } \\
\text { rounded, with some calcareous pebbles (quantile } 3 \mathrm{~cm} \text {, average } 0,5 \mathrm{~cm} \text { ). It is arranged above the } \\
\text { level of planar clasts with an irregular tabular geometry that is interrupted towards the N-terminus of } \\
\text { the section, where its thickness increases. It contains scattered charcoal and few bone fragments. }\end{array}$ \\
\hline MALM.3 & 3 & $24-16 \mathrm{CM}$ & $\begin{array}{l}\text { Yellowish deposit of white limestone clasts cemented with sparse matrix that constitute a breccia. It } \\
\text { contains flat shale pebbles, rounded, while those of limestone are angular (quantile 10-7 cm, avera- } \\
\text { ge } 2 \mathrm{~cm} \text { ). The sparse matrix is clayey silt cemented by carbonates. The arrangement of the pebbles } \\
\text { is chaotic and the lower contact of this deposit is markedly erosive on the underlying. Towards } \\
\text { the mid-north part of the section is affected by dissolution with development of secondary cavities } \\
\text { upholstered by millimetre and centimetre large speleothems. It contains abundant bone fragments } \\
\text { of varying size, charcoals, ochre and flint. }\end{array}$ \\
\hline MALM.2 & 2 & $4-5 \mathrm{CM}$ & $\begin{array}{l}\text { Gray clay silts containing angular gravels of white limestone (quantile } 1 \mathrm{~cm} \text {, average } 0.5 \mathrm{~cm} \text { ) } \\
\text { arranged in a chaotic manner. It is a lense that is interspersed within the MALM. } 1 \text { level, and that is } \\
\text { wedged towards the N. It contains scattered charcoals. }\end{array}$ \\
\hline MALM.1 & 1 & $7-10 \mathrm{CM}$ & $\begin{array}{l}\text { Carbonated deposit with a breccia aspect that has a clay intercalation (MALM.2). This lithostratigra- } \\
\text { phic unit is below (MALM.1b) and above (MALM.1a) of the unit MALM. } 2 \text { sealing the sequence. This } \\
\text { unit is constituted by clast of white limestone (quantile } 7 \mathrm{~cm} \text {, average } 2 \mathrm{~cm} \text { ) cemented by carbona- } \\
\text { tes and in some points there is a whitish silty matrix. It is arranged with a slight inclination towards } \\
\text { the } \mathrm{N} \text { of the section. It contains flint remains and few bone fragments. To top it seems breccia and } \\
\text { its surface is irregular due to the appearance of the angular clasts, together with slightly dark clayey } \\
\text { silts. The whole deposit, breccia and crust, reaches up until the cave wall. }\end{array}$ \\
\hline
\end{tabular}

Table 1: Description of stratigraphic levels of Sector A from bottom to top. / Descripción de los niveles estratigráficos del Sector A.

\begin{tabular}{|c|c|c|c|c|c|c|c|c|c|}
\hline AMS-Lab-ID & Sample ID & Archaeological level & Age (yr BP) & $+/-$ & $\delta 13 \mathrm{C}(\%)$ & Age (yr cal BP) & $+/-$ & Pretreatment & Sample mat. \\
\hline COL4195.1.1 & A 4-6 & Level 3 & 13479 & 60 & -22.4 & 16200 & 90 & AAA & charcoal \\
\hline COL4196.1.1 & A 6.15 & Level 3 & 12498 & 56 & -24.3 & 14710 & 170 & AAA & charcoal \\
\hline COL4197.1.1 & A 6.25 & Level 3 & 12628 & 54 & -21.1 & 14970 & 110 & AAA & charcoal \\
\hline COL4198.1.1 & A 8.17 & Level 6 & 12364 & 55 & -24.0 & 14430 & 180 & AAA & charcoal \\
\hline
\end{tabular}

Table 2: Results of AMS dating. Dates calibrated to CalPal 2019.7. / Resultados de la datación por AMS. Datos calibrados por CalPal 2019.7. 


\subsection{Pollen analysis}

Levels 3 (A825), 5 (A824) and 6 (A823) have been sampled for palynological studies. The extraction of poIlen grains followed standardized acid- and alkalis-based methods (Coûteaux, 1977; Girard and Renault-Miskovsky, 1969; Goeury and Beaulieu, 1979).

The statistical analysis was carried out using the TILIA® and TILIA-GRAPH® software package (Grimm, 1987, 2004). The relative percentages of arboreal, shrub and non-arboreal pollen were calculated on the basis of the aggregate numbers, which were broken down by type, allowing for a general picture of relative proportions of arboreal versus non-Arboreal Pollen to be obtained (AP-NAP). The percentages of spores and of Non-Pollinic Microfossils (NPM) were calculated separately, based on their aggregate number, in order to obtain a consistent picture of the local and regional plant population. The resulting histogram reflects all identified taxa including: four arboreal, two shrubby and fourteen herbaceous taxa; monolet and trileta spores and four Non-Pollinic microfossils (MNP) of diverse nature were also identified (van Geel, 1978; López Sáez et al. 2000; Navarro et al. 2001) (Fig.5 and 6).

The herbaceous taxa (Fig. 6) are divided into groups according to their ecological niches: xeric taxa (Asteraceae liguliflorae, Asteraceae tubuliflorae and Poaceae) and steppic taxa (Chenopodiaceae and Ephedra) which are related to dry conditions, and nitrophilous taxa (Plantago, Rubiaceae and Urtica), which are related to nitrogen-rich soils owing to the presence of animals/livestock. Herbaceous taxa without a clear ecological affinity form a separate group. Other Herbs (Dipsacaceae, Boraginaceae, Fabaceae, Geraniaceae, Sanguisorba and Scrophulariaceae). The high proportion in which these taxa are present may be indicative

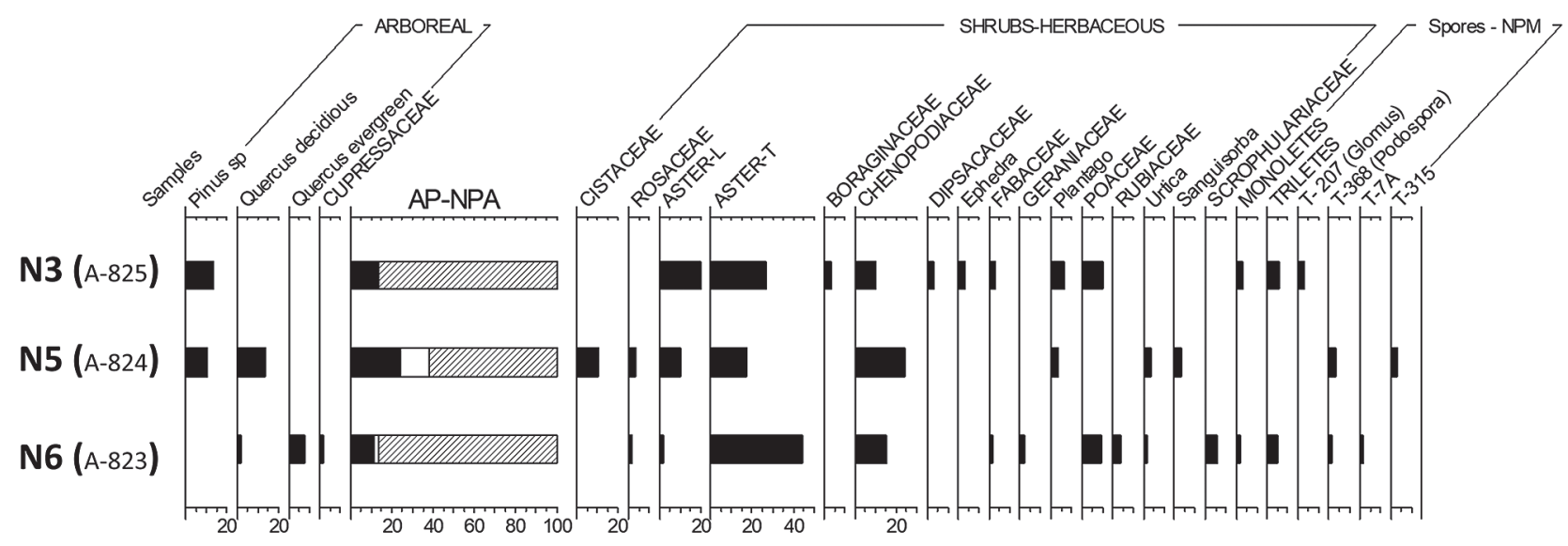

MA, Pollen Histogram (Malalmuerzo)

Fig.5. Pollen histogram. Sample: Level 3 A825 -300 grain, Level 5 A824 -290 grain, Level 6 A823 -520 grain. / Histograma de polen. Muestra: Nivel 3 A825 -300 grano, Nivel 5 A824 -290 grano, Nivel 6 A823 -520 grano.

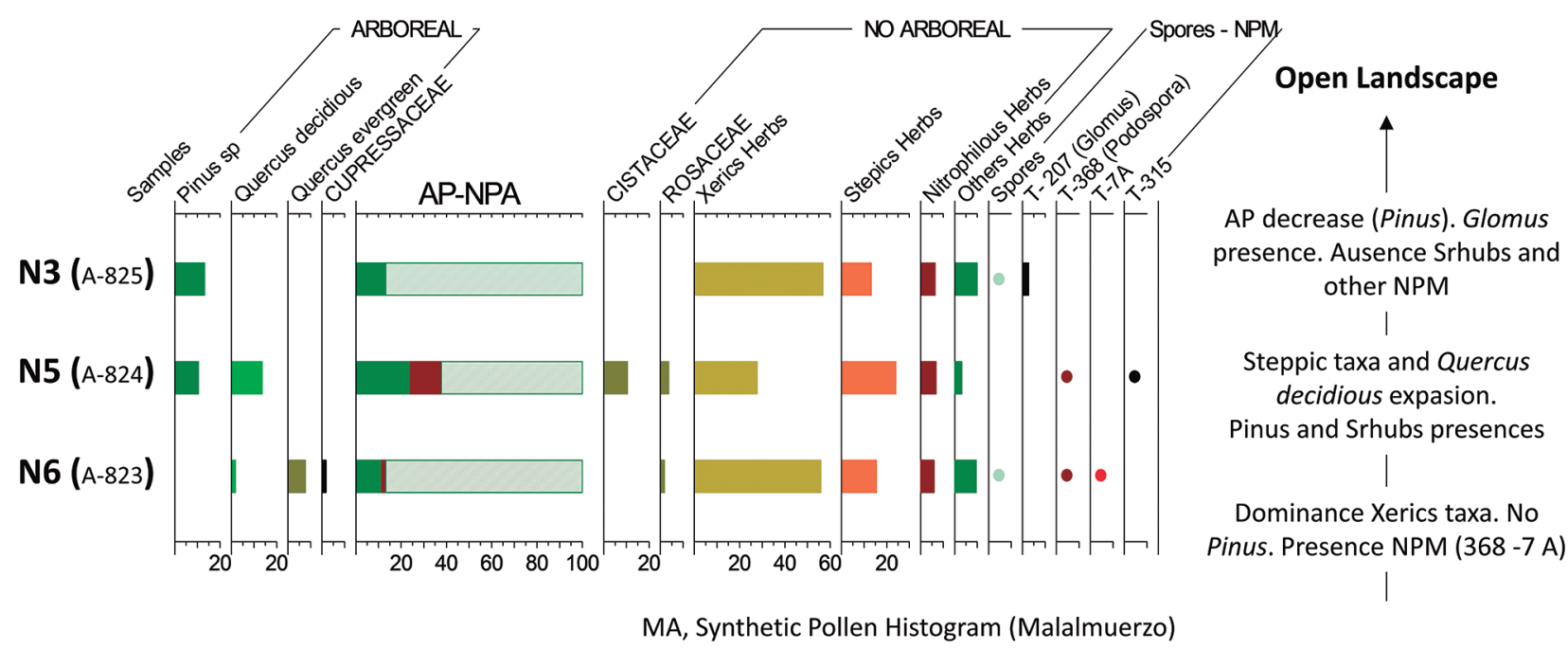

Fig.6. Synthetic pollen histogram. / Histograma de polen sintético. 
of climate amelioration, while a low proportion suggest climate deterioration. However, this characterization includes spores and NPM coprophilous (type 368 or Podospora), type 7A, which are associated to the effects of fire, as well as type 315 related to the presence of some degree of moisture in the soil.

The results (AP-NAP curve), suggest an open landscape dominated by xeric and steppic taxa, developing towards dryer conditions. However, changes in PA and shrub composition are observed. At the lower levels of the sequence, Quercus evergreen, Quercus deciduous, Cupressaceae and Rosaceae predominate; at intermediate levels, the presence of Pinus sp, only with Quercus deciduous, Cistaceae, Rosaceae, and a greater proportion of steppic taxa are attested; finally, at the upper levels of the sequence, the decreasing AP values and diversity (only pine trees are attested), the disappearance of shrubs, the presence of Glomus, and the increase of xeric taxa, point to increasingly dryer climatic conditions. Under these conditions, the presence of nitrophilous and coprophilous taxa and the NPM type $7 \mathrm{~A}$ (indicating the incidence of fire) and type 315 could indicate the intensification of human presence.

\subsection{Anthracological evidence}

The amount of charcoal available for analysis was not huge, due to the limited size of the excavation area (Tab. 3). The results are therefore not statistically representative, and should be considered solely in terms of presence-absence.

- Juniperus $t$ phoenicea seems to be the best represented taxon among the stratified charcoals and those identified at the wet sieve. This species is characteristic of Mediterranean regions and is chiefly found in the east and especially the southeast of the Iberian Peninsula. This taxon has been documented at the anthracological level in some Paleolithic sites of Valencia i.e. Tossal de la Roca, Santa Maira, Cendres (Uzquiano, 1997; Badal and Carrión-Marco, 2001; Carrión et al. 2010; Badal et al. 2012).
- Pinus nigra appears in small numbers, as is also the case with the deciduous Quercus. Both taxa, especially the black pine, have also been documented by charcoal analysis in Palaeolithic sites located in the south and southeast of the Iberian Peninsula (Carrión et al. 2010; Badal et al. 2012).

- Identified shrubs include Rhamnus alaternus and Erica sp. These taxa appear rarely and are unevenly distributed (González-Sampériz et al. 2010).

In bio-climatic terms, the charcoal assemblage seems to indicate a Supra-Mediterranean open landscape. All these taxa have excellent qualities as fuel and were abundantly used as firewood by the Magdalenian groups that occupied the cave between 16-14 ka cal BP.

\subsection{Lithic assemblage}

In total 3947 lithic artefacts were collected during the archaeological intervention from the various areas of the cave.

89 artefacts were found on top the archaeological sequence MALM 16 SUP.1.2.; 841 of them came from the soil of the niche MALM 16 SUP.2.1., 83 from MALM 16 SUP.3.1, which are the natural holes located on the roof of the niche and 2317 from MALM SUP.EXT.7, which represents superficial finds from the entrance of the niche, the area that was excavated in the 1980s.

The stratified material from Sector A comprises 617 pieces (Tab. 4). 549 of the artefacts were collected during the wet-sieving of sediments, while 68 were recorded three-dimensionally during excavation.

The large number of pieces collected in wet-sieving is due to their small size and their cementation within the crusts, conditions that complicated their extraction during excavation. For the technological study of the industry and the technical processes involved in their production we use the Analytical Logic System (Carbonell and Mora, 1986).

\begin{tabular}{|c|c|c|c|c|c|c|c|}
\hline \multicolumn{8}{|c|}{ MALALMUERZO CAVE (MALM 16 SECTOR A) } \\
\hline Archaeological levels & 1 & 2 & 3 & 4 & 5 & 6 & Wet-sieving \\
\hline Taxa & $\mathbf{N}$ & $\mathbf{N}$ & $\mathrm{N}$ & $\mathrm{N}$ & $\mathrm{N}$ & $\mathrm{N}$ & $\mathbf{N}$ \\
\hline Juniperus t phoenicea & 2 & & 12 & & & 7 & 101 \\
\hline Pinus t nigra & & & & & & & 9 \\
\hline Quercus caducifolio & & & & & & & 1 \\
\hline Rhamnus alaternus & & & & & & & 7 \\
\hline Erica sp & & & & & & & 2 \\
\hline Indeterminables & & & & & & 1 & 3 \\
\hline TOTAL & 2 & & 12 & & & 8 & 123 \\
\hline Bone & & & & 2 & & 1 & 3 \\
\hline
\end{tabular}

Table 3: Results of charcoal analysis. / Resultados del análisis de carbón vegetal. 


\begin{tabular}{|c|c|c|c|c|c|c|c|c|c|c|c|c|c|c|c|c|c|c|c|c|c|c|}
\hline \multirow{2}{*}{$\begin{array}{l}\text { Lithic industry } \\
\text { Malalmuerzo } 2017\end{array}$} & \multicolumn{5}{|c|}{ BN1G } & \multicolumn{6}{|c|}{ BP } & \multicolumn{4}{|c|}{ ORT } & \multicolumn{6}{|c|}{ BN2G } & \multirow[t]{2}{*}{ TOTAL } \\
\hline & U & B & MP & $\mathbf{P}$ & TOTAL & SD & I & LE & C & H & TOTAL & $E$ & DES & GB & TOTAL & $\begin{array}{l}\text { G11/ } \\
\text { B11 }\end{array}$ & D21 & LD11 & LD21 & B11 & TOTAL & \\
\hline $\begin{array}{l}\text { Malm16 sector A. } \\
\text { wet-sieving }\end{array}$ & & & & & & & 53 & 1 & 7 & 43 & 104 & 403 & 23 & 16 & 442 & & 1 & 2 & & & 3 & 549 \\
\hline \multicolumn{23}{|l|}{$\begin{array}{l}\text { Malm16 sector A. } \\
\text { Archaeological levels }\end{array}$} \\
\hline \multicolumn{23}{|l|}{ MALM16 A Level 1} \\
\hline MALM16 A Level 2 & & & & 1 & 1 & & & & & 1 & 1 & & & & & & & & 1 & & 1 & 3 \\
\hline MALM16 A Level 3 & 1 & 1 & & & 2 & 1 & 16 & 1 & 2 & 9 & 29 & 2 & 2 & 1 & 5 & 1 & & 1 & & 1 & 3 & 39 \\
\hline MALM16 A Level 4 & & & 1 & & 1 & & 3 & & & 4 & 7 & & 1 & & 1 & & & 1 & & & 1 & 10 \\
\hline \multicolumn{23}{|l|}{ MALM16 A Level 5} \\
\hline MALM16 A Level 6 & & 1 & & 1 & 2 & 1 & 10 & 1 & & 1 & 13 & & & & & & & 1 & & & 1 & 16 \\
\hline TOTAL ANALIZED & & & & & 6 & & & & & & 154 & & & & 448 & & & & & & 9 & 617 \\
\hline
\end{tabular}

Table 4: Lithic assemblage of MALM16 Sector A. / Conjunto lítico de MALM16 Sector A.

BN1G-Cores: U-Unidirectional core, B-Bidirectional core, MP-Multipolar core, P-Prismatic core

BP-Flakes: SD-Semi-cortical flakes, I-simple flakes, LE-Levallois, C-Crested flakes, $\mathrm{H}$-Blade

ORT-Other debris: E-small flakes, DES-Debris, GB-Burin fragment.

BN2G-Modified pieces: G11/B11-Single end-scraper/burin. D21-. Notched piece. LD-11-. Partially backed blade. LD21- Backed blade. B11- Burin.

The lithic industry (Fig. 7, 8, 9, 10) fits within the Magdalenian techno-complex, which matches the radiocarbon dates (Tab. 2). Only the lithic assemblage found in primary position in the archaeological profile will be presented here.

The material recorded three-dimensionally comprises 6 cores, 50 blanks, 6 small blanks and debris including 1 burin spall and 6 formal tools. More than half of the material comes from level 3. Among the cores, the presence of two prismatic cores is significant. Two bidirectional cores document the preparation for the production of laminar flakes and blades. Preparation and production are documented either by 2 crested blades. About one third of the blanks are blades and bladelets. From the 6 formal tools 4 are backed pieces. The high proportion of blades and bladelets is also evident in the sieved material. Simple flakes and blades are the two most common classes of blanks. The presence of burins and burin spalls fits together with the bladelets and backed pieces perfectly into the technological context of the Magdalenian. Overall, the analysis of the lithic material indicates the presence of artefacts belonging to different operational sequence, including preparation, production, correction and re-preparation on-site.

The raw material used for the stone artefacts includes several varieties. Especially predominant are massive light-coloured flints, ranging from bluish white and grey to brown and black. Ooliths and banded pieces, as well as radiolarites, are likewise present at the site, although in smaller numbers. Some pieces present remains of chalk and calcareous concretions due to them being in contact with water.

Malalmuerzo cave is part of a series of Upper $\mathrm{Pa}$ leolithics sites in the area of Granada, includings Cueva Horá, Cueva del Pantano del Cubillas, Cueva de las Ventanas and Las Cuevas de Cozvíjar. All these sites are described by their lithic assemblages as belonging to the so called Solutreo-Gravettian tradition (Toro and Almohalla, 1979; Toro et al. 1980, Sánchez, 2004; Riquelme, 2002; Aura et al. 2012; Cascalheira and Bicho, 2015; Straus, 2018). This technocomplex corresponds to an evolved extra-cantabrian Solutrean and is characterized by a decrease in the frequency of barbed and tanged points, by the presence of a substantial number of shouldered points with abrupt retouch and an increase of in the number of backed bladelets. These sites, both caves and open air sites, such as Pantano del Cubillas (Toro and Ramos, 1985) and Peña de la Grieta in Porcuna, Jaén (Arteaga et al. 1998), are often situated close to natural pathways and strategic positions. Their distribution is probably indicative of a wider settlement pattern, including both coastal and inland settlements. Prominent among these are Nerja cave (Aura et al. 2010), Victoria cave (Fortea, 1973), Hoyo de la Mina, the Duende (Cortés, 2003), shelter 4 and 6 of Complejo Humo in Málaga (Ramos et al. 2005; Cortés, 2006), the Pirulejo in Córdoba (Cortés et al. 2008) and Gorham`s cave in Gibraltar (Giles et al. 2001), all of which present Magdalenian chronologies.

To date, no deposits of Magdalenian chronology have been located in the region of Granada, with the exception of Malalmuerzo. However, the lithic industry classed as Magdalenian collected by microprospection in the shelter 3 Tajos de Marchales in Colomera, Granada (García-Franco and Morgado, 2018), must be mentioned. 


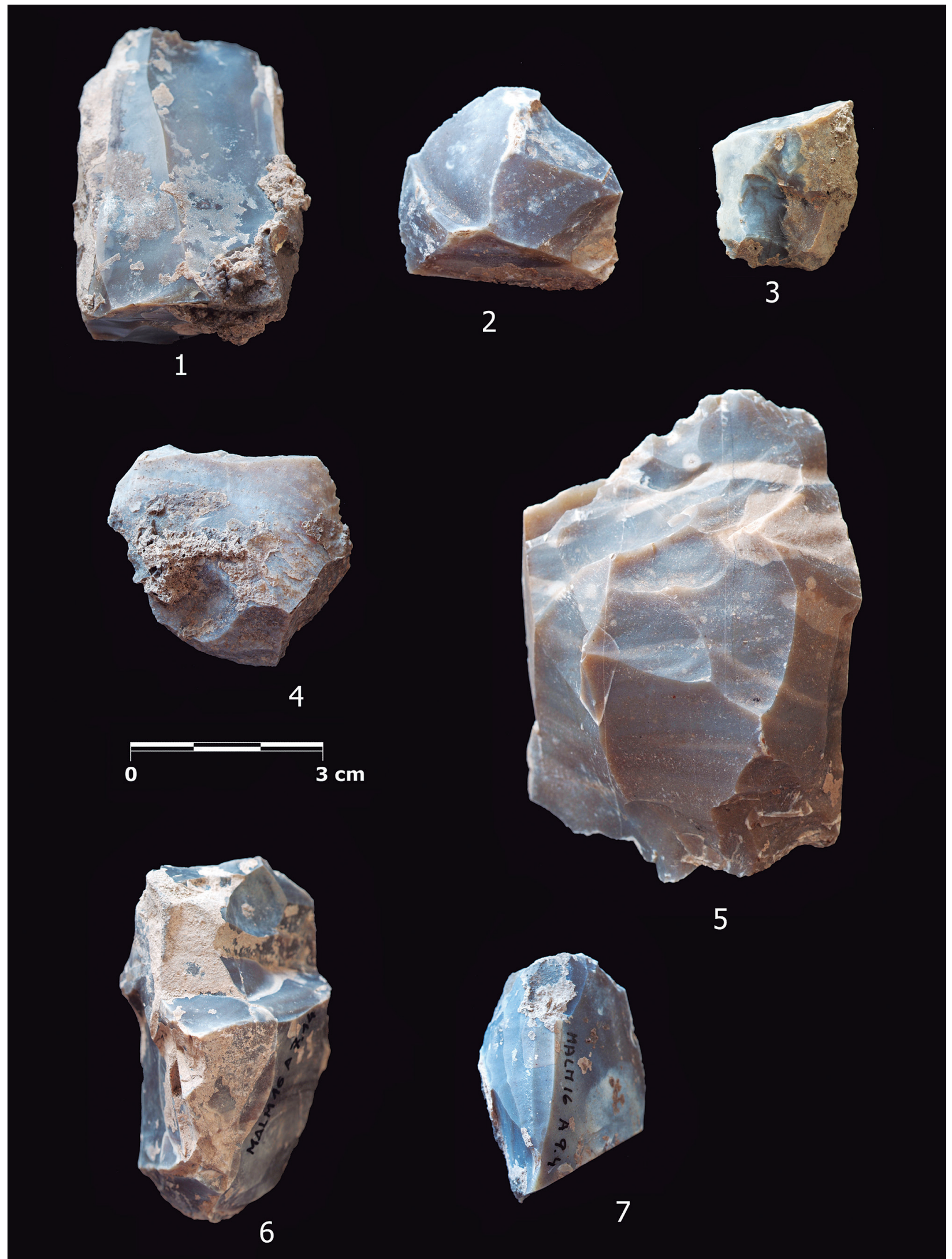

Fig.7. Cores and flakes of Sector A. 1 Core and 2-4 flakes of archaeological level 3; 5-7 Cores archaeological level 6. / Núcleos y lascas del Sector A. 1 Núcleo y 2-4 lascas del nivel arqueológico 3; 5-7 Núcleos del nivel arqueológico 6. 


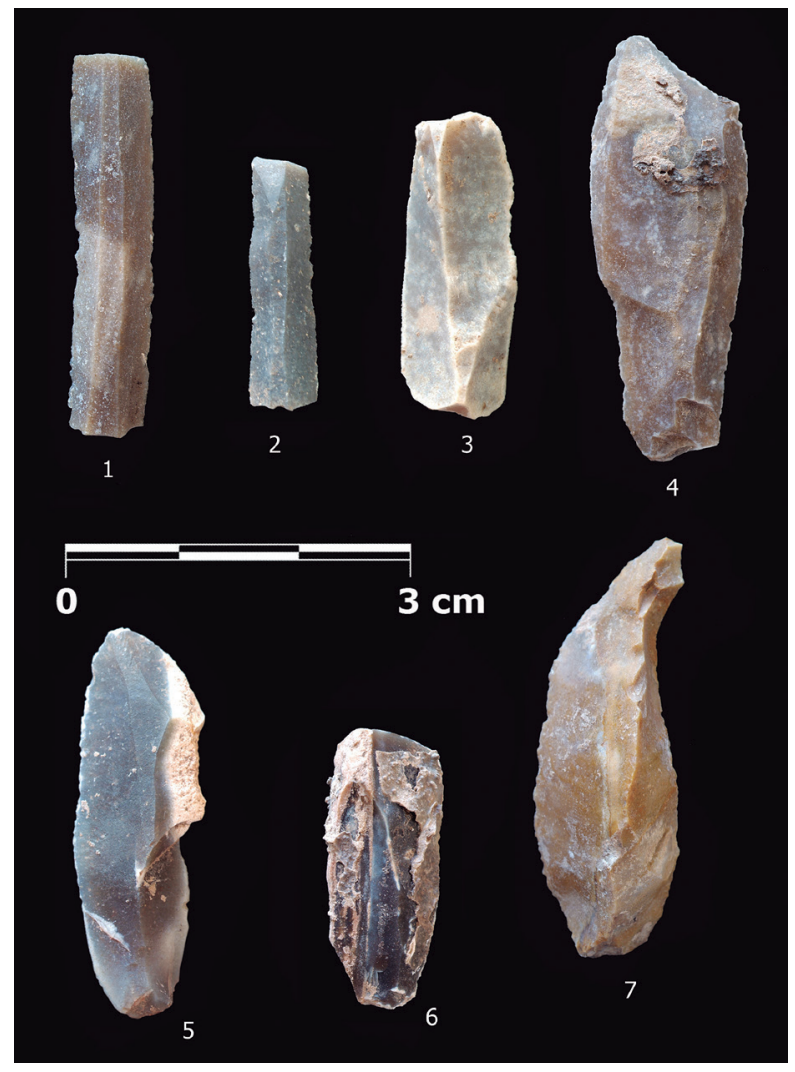

Fig.8. Blades and bladelets of archaeological level 3/ Sector A. 1-6 Blades; 7 Crested blade. / Hojas y hojitas del nivel arqueológico 3 Sector A. 1-6 Hojas; 7 hoja en cresta.

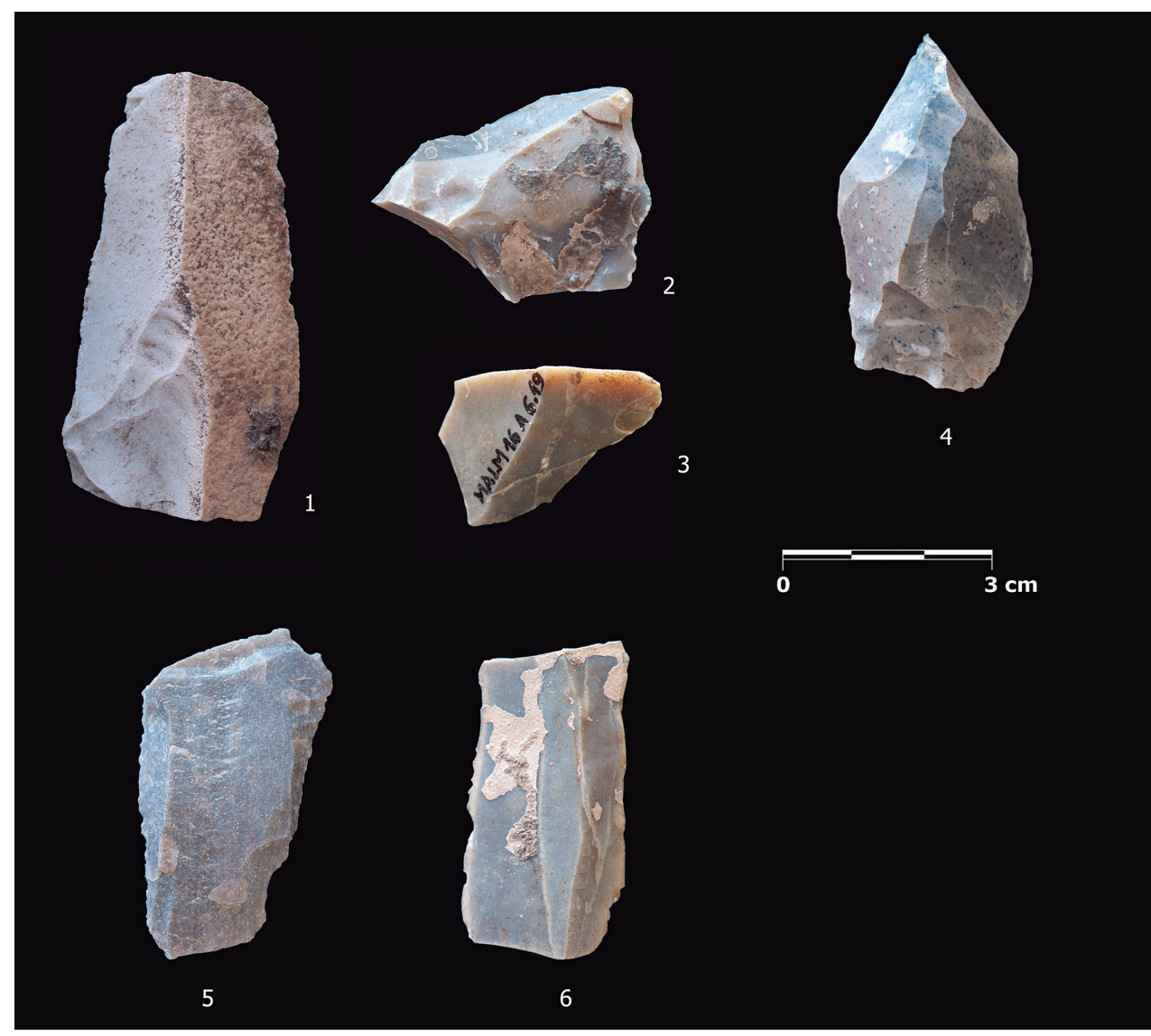

Fig.9. Flakes and blades of archaeological level 6 Sector A. Lascas y hojas del nivel arqueológico 6 Sector $A$. 


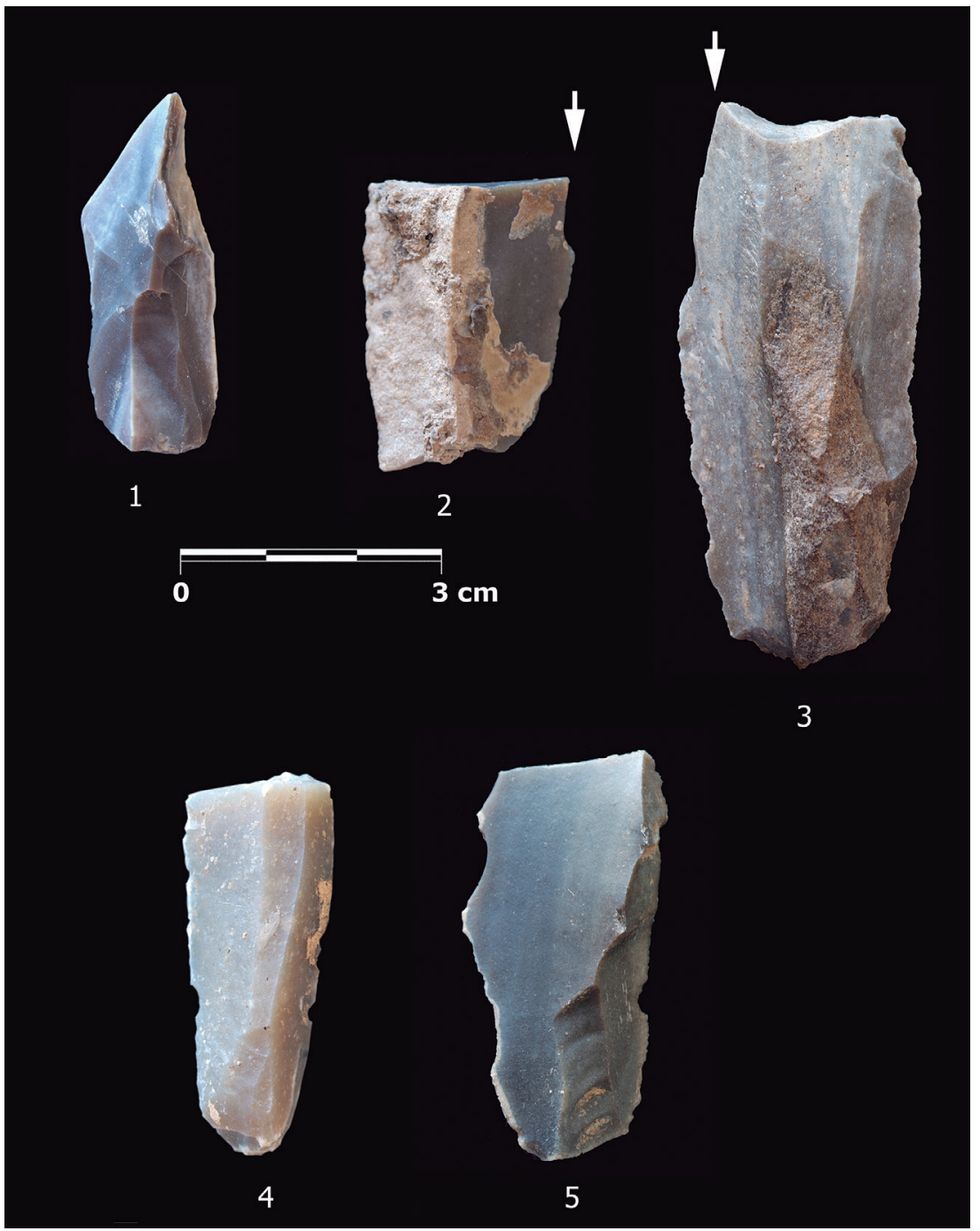

Fig.10. Backed bladelet and burins Sector A. 1 Backed bladelet of archaeological level 2., 2, 3: Burins of archaeological level 3., 4: Backed bladelet of archaeological level 4., 5: Backed bladelet of archaeological level 6. / Láminas de dorso y buriles del Sector A. 1 lámina de dorso del nivel arqueológico 2; 2-3 Buriles nivel arqueológico 3; 4 lámina de dorso del nivel arqueológico 4; 5 lámina de dorso del nivel arqueológico 6 .

\subsection{Rock art}

During excavation, remains of red pigment (Sector A), were detected on the wall of the cave (Fig. 11) (Cabello et al. 2019). Two motifs, in close proximity to one another, could be recognized. One can be clearly identified as the forepart of a horse facing right. The second one is a concentration of a series of lines close to the equid. Documentation of the art was done by digitizing the graphical content, both the new red figure of the horse, which is presented here, as well as the other paintings discovered in 1983.

This was achieved by means of analog photography (35 $\mathrm{mm}$ and $60 \mathrm{~mm}$ format film), as well as by using tracing paper. Torches and cold white LED lighting, with infrared filters, were used, which produced a higher quality image of the equine figure.

The representation of the horse is typical of the Solutrean, in terms of size, style and technique. It is but a silhouette, and no interior details are depicted. Only one limb, which presents a pointy profile, is depicted. The mane is represented as a crest. The belly protrudes markedly and the back is concave in profile. All these features are typical for the Solutrean (Graziosi, 1974). The painting was probably executed using the tip of a brush. The line of the slightly arched neck is divided into two segments, shaping the mane that covers the ears and ends in a curve over the forehead.

The face, which is slightly rounded, is represented by the curve of the muzzle, also divided into two segments to depict the lips. The curve traced by the lower lip is much more pronounced and is neatly connected with the arched jaw. The jaw culminates in a straight angle that outlines the chest. The muscle at the lowest part of the chest is clearly highlighted. Two lines are used to represent the front leg and thus complete the image of the horse which, although simple and poorly preserved, is undoubtedly an art work from the upper Paleolithic. The eye is filled by a brown spot. 

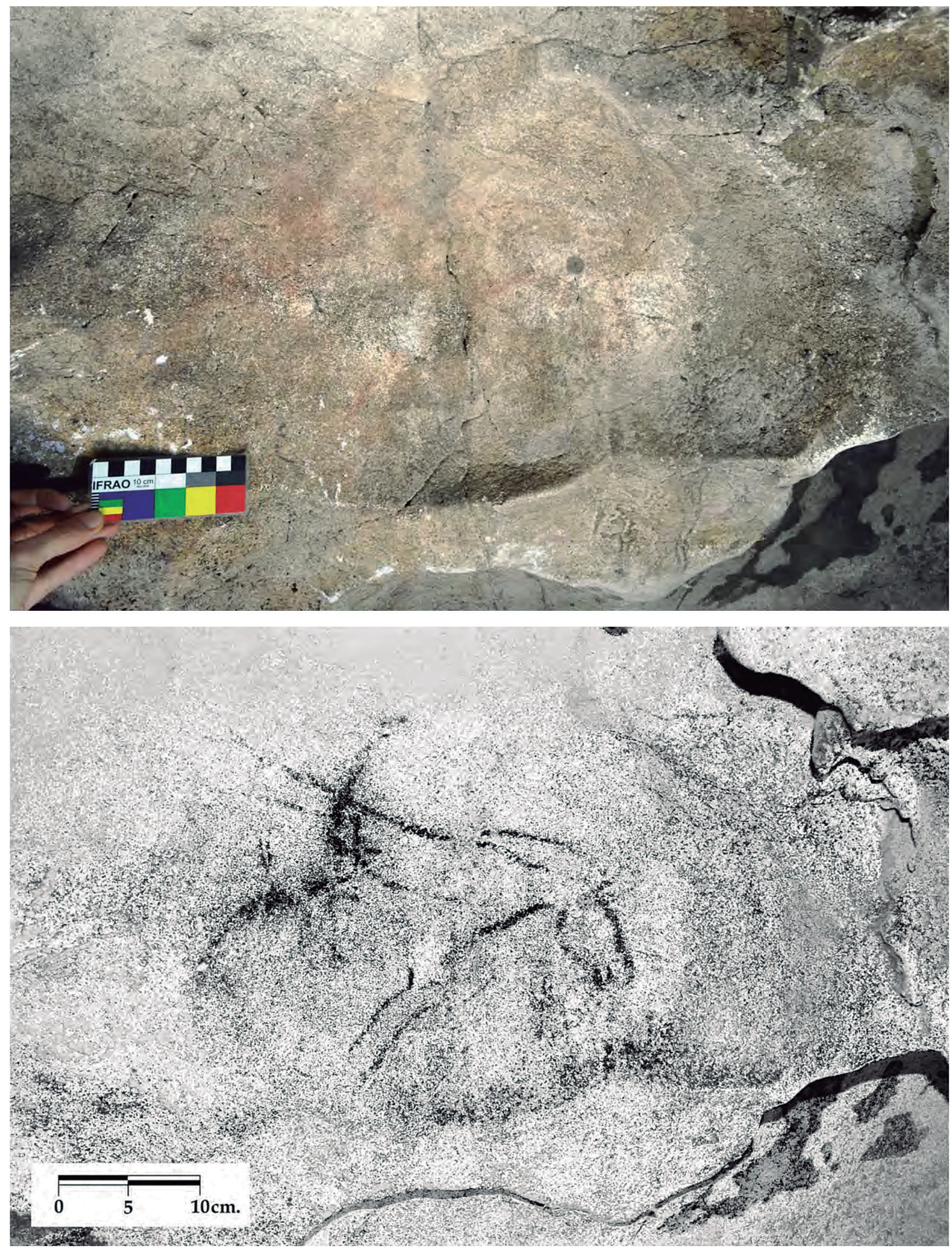

Fig.11. Newly discovered rock art in Sector A. Frontal part of a horse and a series of lines close to the equid. / Nuevo descubrimiento de arte rupestre en el Sector A. Parte frontal de un caballo y una serie de líneas en la parte central del équido. 
The other motif is located to the left side of the horse, below the rump, where the flank of the animal should be. It consists of various curved lines that intertwine with the blurry part of the horse's back. Until further research provides a better understanding of the piece, we must regard the motif as 'undetermined' due to its poor state of preservation.

More Palaeolithic paintings have been documented (Cantalejo, 1983) farther inside the cave, and these can be compared to the newly discovered motif. Altogether, four techniques have been attested to date:

- Red paintings executed with the fingers (numerous examples).

- Red paintings executed with a brush, either coarse or fine (three horses and one bovid) probably using a solution of iron oxide in water.
- Black paintings executed with pieces of charcoal.

- Engraved lines, probably executed with the cutting edge of lithic artefacts.

While taking samples from the profile, the excavation team found a plaquette with small red spots (Fig. 12). This was discovered in association with lithic artefacts and charcoal dated to $14430 \pm 180$ cal BP (COL4198.1.1). In addition, other large stones with remains of red pigment on their surface were also found near the excavated area, suggesting the use of mineral pigments (iron oxide) in parts of the cave which are easily accessible. In almost every case, these marks were found in limestone blocks or nodules, but some were identified on sandstone blocks. These marks have no definite shape, but are very clear, and might be indicative of the preparation of red colorants.

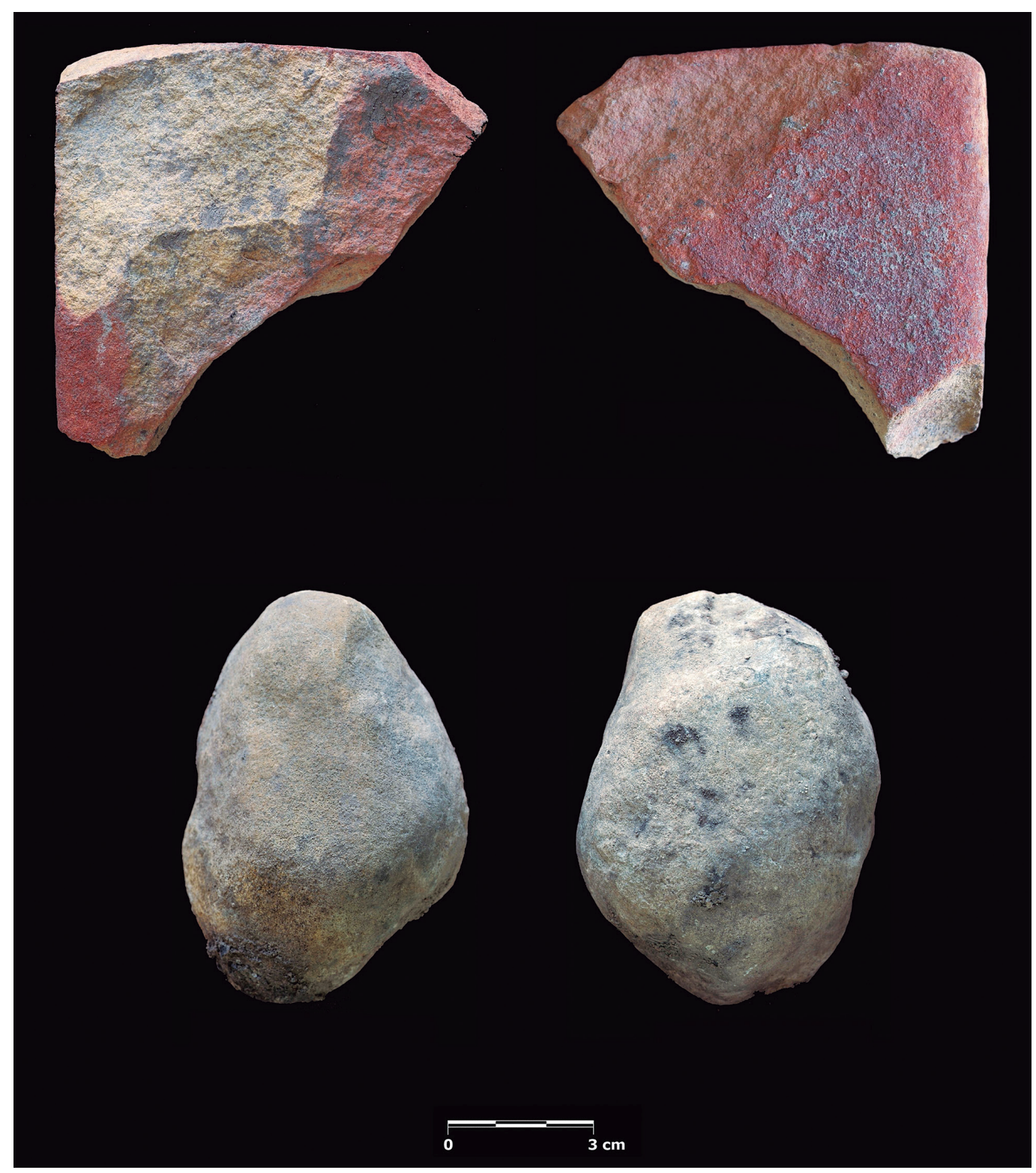

Fig.12. Plaquette with red spots and associated sandstone pebble rock from archaeological level 6. / Plaqueta con manchas rojas asociada a un guijarro de arenisca del nivel arqueológico 6. 
They display typical patterns of Palaeolithic surface modification:

- Two clear parallel, engraved lines, most probably cut marks caused during the butchering of the animal.

- A sequence of four parallel, diagonal engraved lines on the flat surface of a bone tool (probably a point or round stick), suggesting an artistic, but unfinished, graphic representation.

- Use wear traces on the tip of a pointed bone tool, which also features a homogenous and neat undulating line, which is clearly artistic in nature.

\section{DISCUSSION AND CONCLUSIONS}

The Malalmuerzo cave presents evidence of human occupation in the final stages of the Upper Palaeolithic, during the Solutrean and the Magdalenian. After the Palaeolithic occupation the site was used as burial place in the Neolithic. We consider that Malamuerzo cave was an important site at different times during Upper Paleolithic. This may be due to its strategic location. As a natural passage between the interior and the coast, crossing mountains and valleys in combination with karstic features it was probably frequently used by human groups moving from the cost to the inland and vice versa.

New excavation data from MALM 16 SECTOR A confirm the occupation of the cave during the Magdalenian. Together with other sites of the Province of Granada like Cueva de la Carihuela (Fernández et al. 2007) or Tajo de los Marchales (García-Franco and Morgado, 2018). Malalmuerzo demonstrates that the Magdalenian occupation was not restricted to the coastal strip but reached into the interior and sometimes reoccupied caves which had previously been used by Solutrean groups.

Sediments from the Magdalenian partly covered two unknown new motifs of rock art. The rock art in the other parts of the cave of Malalmuerzo has been placed by stylistic analysis into the Solutrean period. The depictions can be formally ascribed to those of other sites of the socalled "Mediterranean Area" as La Pileta (Sanchidrián and Márquez, 2003), Ardales (Cantalejo et al. 2006), Nerja (Sanchidrián and Márquez, 2003), Navarro (Sanchidrián, 1982) en Málaga, Palomas I en Cádiz, El Morrón (Sanchidrián et al. 2017) en Jaén, Ambrosio (Ripoll and Muñoz, 2019) en Almería, El Niño (Gárate and García, 2011) en Albacete o Parpalló (Pericot, 1942) en Valencia. The new discovered motives support this chronology.

Beside the artistic manifestations from the Solutrean, domestic activities are documented by the Magdalenian occupations. The lithic assemblage displays different operational sequences including the production of laminar flakes and blades as well as initial stages of lithic production on-site and re-sharpening of tools. Domestic activities can be made probable also by the anthracological study. All taxa documented feature ex- cellent qualities and were used as firewood, being the majority the presence of Juniperus t phoenicea. In addition, the study of pollen includes a taxa of type 7A associated to the presence of fire.

The study of animal remains from the wet-sieving material display a predominance of species such as rabbit (Oryctolagus cuniculus), ibex (Capra pyrenaica) and red deer (Cervus elaphus). The bones shows a high degree of fragmentation related to the butchery processes to extract bone marrow and a large part of the remains shows traces of fire.

Extreme climatic conditions during the Last Glacial Maximum, c. 25-19 ka cal BP caused glaciers to advance, as well as increasingly arid conditions and marine regression. These phenomena did not affect the Iberian Peninsula in the same way as they did the rest of the European continent. However, although in the Peninsula the glacial climate was less severe than in northern Europe and the regression of the sea level freed large areas for human occupation, the Solutrean groups (Straus, 2018) were forced to seek refuge areas. This would explain the abundance of deposits in peripheral regions (Cascalheira et al. 2012; Schmidt et al. 2012; Straus, 2012) including the southern Iberian Peninsula. While in the Solutrean there is a significant increase in the number of sites in the south (Schmidt et al. 2012), site density drops sharply in the Magdalenian, suggesting a decline in human settlement (Weniger et al. 2019). This is probably due to the extremely dry conditions prevailing in Southern Iberia during the Heinrich Event 1 (Ludwig et al. 2018; Camuera, et al. 2019). Interior regions of the Iberian Peninsula, hence not only the coastal areas, became populated during the Solutrean. Gastropod, scaphopod and marine bivalve consumption is attested, for instance at Tajo de Jorox cave (Simón et al, 2006) or Ambrosio (Avezuela and Martínez, 2012), and sometimes even before the Solutrean period, for instance in Pileta (Cortes et al. 2016), suggesting that these human groups had strong links with the coast.

In the north of the Iberian Peninsula, in contrast to the south, an expansion of the Magdalenian settlement area is attested (Weniger et al. 2019), leading to a phenomenon of regionalization, settlement pattern specialization and seasonality (Fullola et al. 2006). A part of the Solutrean sites were reoccupied in the Magdalenian. These multi-period sites are probably flagging core human exploitation areas (Weniger et al. 2019). Malalmuerzo belongs to this category as is the case with Nerja (Aura 1995, Aura et al. 2010) and El Pirulejo (Asquerino, 1988; Cortés et al. 2008).

This wider context highlights the importance of Malalmuerzo cave for the study of the Upper Paleolithic, not only in the province of Granada, but also in the south of the Iberian Peninsula more broadly, especially considering the paucity of available evidence for the Magdalenian period. To date, most of this evidence, with few exceptions, has been found in connection with sites in 
the province of Malaga (Cortés, 2002); important sites in this regard are: Cueva de Nerja (Aura, 1986; Aura and Pérez, 1998), Hoyo de la Mina, Cueva de la Victoria (Fortea, 1973) and El Pirulejo (Asquerino, 1988; Cortés et al. 2008).

To understand the development of the Andalusian Magdalenian and its relationship with the Solutrean further research is needed.

\section{REFERENCES}

Alix, P.H., Pelegrin, J., Deloge, H., 1995. Un débitage original de lamelles par pressione au Magdalénien du Rocher-de-laCaille (Loire, France). Paleo 7, 187-199.

Arteaga, O., Ramos, J., Roos, A.M., 1998. La Peña de la Grieta (Porcuna, Jaén). Una nueva visión de los cazadores-recolectores del mediodía atlántico-mediterráneo desde la perspectiva de sus modos de vida y de trabajo en la Cuenca del Guadalquivir. In: Sanchidrián, J.L., Simón, M.D. (Eds.), Las culturas del Pleistoceno Superior en Andalusia, 75-110. Málaga.

Asquerino, M.D., 1988. Avance sobre el yacimiento magdaleniense de El Pirulejo: Priego de Córdoba. Estudios de Prehistoria Cordobesa 4, 59- 68.

Aura, J.E., 1986. La ocupación magdaleniense de la Cueva de Nerja (la Sala de la Mina). La Prehistoria de la Cueva de Nerja (Málaga). Paleolítico y Epipaleolítico. Trabajos sobre la Cueva de Nerja 1, 205-268.

Aura, J.E., 1995. El Magdaleniense Mediterráneo: La Cova del Parpalló (Gandía, Valencia). Serie de trabajos varios 91. Valencia.

Aura. J.E., Pérez, C.I., 1998. ¿Micropuntas dobles o anzuelos? Una propuesta de estudio a partir de los materiales de la Cueva de Nerja. In: Sanchidrián, J.L., Simón, M.D. (Eds), Las culturas del Pleistoceno Superior en Andalusia, 339-348. Málaga.

Aura, J.E., Jordá Pardo, J.F., Pérez Ripoll, M., Badal, E., Morales, J.V., Avezuela, B., Tifagom, M. Jardón, P., 2010. Treinta años de investigación sobre el Paleolítico superior de Andalucía: la Cueva de Nerja (Málaga, España). In: Mangado, X. (Ed.), El Paleolítico superior peninsular. Novedades del siglo XXI. Homenaje al Profesor Javier Fortea, 149-172. Monografíes 8. Seminari d'Estudis i Recerques Prehistòriques, Universidad de Barcelona.

Aura, J.E., Tiffagom, M., Jordá Pardo, J.F., Duarte, E., Fernández de la Vega, J., Santamaria D., De la Rasilla, M., Vadillo, M., Pérez-Ripoll, M., 2012. The Solutrean-transition: A view from Iberia. Quaternary International 272-273, 75-87.

Avezuela, B., Álvarez, E., 2012. Los objetos de adorno-colgantes durante el Solutrense en la Península Ibérica. In: Ripoll, S., Avezuela, B., Jordá, J.F., Muñoz, F.J. (Eds.), El Solutrense. Centenario de las excavaciones en La Cueva de Ambrosio, 323-332. Espacio, Tiempo y Forma. Serie I, Nueva época. Prehistoria y Arqueología.

Badal, E., Carrión, Y., Figueiral, I., Rodríguez-Ariza, M.O., 2012. Pinares y enebrales. El paisaje solutrense en Iberia. In: Ripoll, S., Avezuela, B., Jordá, J.F., Muñoz, F.J. (Eds.), E Solutrense. Centenario de las excavaciones en La Cueva de Ambrosio, 259-271. Espacio, Tiempo y Forma. Serie I, Nueva época. Prehistoria y Arqueología.

Badal, E., Carrión, Y., 2001. Del Glaciar al Interglaciar: los paisajes vegetales a partir de los restos carbonizados hallados en las cuevas de Alicante. In: Villaverde, V. (Eds), De Neanderta- les a Cromañones. El inicio del poblamiento humano en tierras valencianas, 21-40. Universidad de Valencia.

Cabello, L., Cantalejo, P., Espejo, Mª.M., Buendía, A., 2019. Malalmuerzo Cave (Granada, Spain): A Revision of its Art and Archaeology. In: Schmidt, I., Cascalheira, J., Bicho, N., Weniger, G. (Eds), Human Adaptations to the Last Glacial Maximum: The Solutrean and its Neighbors, 453-476. University of Cologne, University of Bonn and RWTH Aachen University.

Camuera, J., Jiménez-Moreno, G., Ramos-Román, M.J., García-Alix, A., Toney, J.L., Scott Anderson, R., Jiménez -Espejo, G., Bright, J., Webster, C., Yanes, Y., Carrión. J.S., 2019. Vegetation and climate changes during the last two glacial-interglacial cycles in the western Mediterranean: A new long pollen record from Padul (southern Iberian Peninsula). Quaternary Science Reviews 205, 86-105.

Cantalejo, P., Maura, R., Espejo, M.Mª, Ramos, J., Medianero, J., Aranda, A., Durán, J.J. 2006. La Cueva de Ardales: arte prehistórico y ocupación en el Paleolítico Superior. Estudios 1985-2005. Málaga.

Cantalejo, P., 1983. La cueva de Malalmuerzo (Moclín, Granada): nueva estación con Arte Rupestre Paleolítico en el área mediterránea. Antropología y Paleoecología Humana 3, 59-99.

Carbonell, E., Mora, R., 1986. El sistema lógico-analitic. La teoría del 'transfer' en l'estudi dels complexes litics. Societat Catalana d'Arqueologia, Barcelona.

Carrión, J.S., Fernández, S., González Sampériz, P., Gil Romera, G., Badal, E., Carrión Marco, Y., López Merino, L., López Sáez, J.A., Fierro, E., Burjachs, F., 2010. Expected trends and surprises in the Lateglacial and Holocene vegetation history of the Iberian Peninsula and Balearic Islands. Review of Palaeobotany and Palynology 162, 458-475.

Carrión, J.S., Fernández S., González-Sampériz, P., López-Merino, L., Peña, L., Burjachs, F., López- Sáez, J.A., García-Antón, M., Carrión-Marco, Y., Uzquiano, P., Postigo, J.M., Barrón, E., Allué, E., Badal, E., Dupré, M., Fierro, E., Munuera, M., Rubiales, J.M., García-Amorena, I., Jiménez-Moreno, G., Gil-Romera, G., Leroy, S., García-Martínez, M.S., Montoya, E., Fletcher, W., YII, E., Vieira, M., Rodríguez-Ariza, M.O., Anderson, S., Peñalba, C., Gil-García, M.J., Pérez-Sanz, A., Albert, R.M., Díez, M.J., Morales, C., Gómez-Manzaneque, F., Parra, I., Ruiz-Zapata, B., Riera, S., Zapata, L., Ejarque, A., Vegas, T., Rull, V., Scott, L., Andrade, A., Pérez-Díaz, S., Abel-Schaad, D., Moreno, E., Hernández- Mateo, L., Sánchez-Baena, J.J., Riquelme, J.A., Iglesias, R., Franco, F., Chaín, C., Figueiral, I., Grau, E., Matos, M., Jiménez-Espejo, F., Arribas, A., Garrido, G., Finlayson, G., Finlayson, C., Ruiz, M., Pérez- Jordá, G., Miras, Y., 2012. Paleoflora y Paleovegetación de la Península Ibérica e Islas Baleares: Plioceno-Cuaternario. Ministerio de Economía y Competitividad, Madrid.

Carrión, F. and Contreras, F., 1979. Yacimientos neolíticos en la zona de Moclín, Granada. Cuadernos de Prehistoria de la Universidad de Granada 4, 65-70.

Carrión, F., Contreras, F., 1983. La Cueva de Malalmuerzo (Moclín, Granada). Un yacimiento del Neolítico antiguo en la Alta Andalusia. In Actas del XVI Congreso Arqueológico Nacional, 65-70. Murcia, Cartagena.

Cascalheira, J., Bicho, N., Marreiros, J., Pereira, T., Évora, M., Cortés, M., Gibaja, J., Manne, T., Regala, F., Gonçalves, C., Monteiro, P., 2012. Vale Boi (Algarve, Portugal) and the Solutrean in Southwestern Serie I, Nueva época. Prehistoria y Arqueología 5, 455-67. 
Cascalheira, J., Bicho, N., 2015. On the Chronological Structure of the Solutrean in southern Ibéria. Plos One 10 (9). https:// doi.org/10.1371/journal.pone.0137308.

Cortés, M., Simón, M.D., Morales-Muñiz, A., Lozano, M.C., Vera, J.L., Odriozola, C., 2016. La caverna iluminada: una singular lámpara Gravetiense arroja luz sobre el arte parietal de la cueva de La Pileta (Benaoján, Málaga). Trabajos de Prehistoria 73(1), 115-127.

Cortés, M., 2006. El Paleolítico Superior del Complejo del Humo (Málaga) en el contexto de la ocupación de la franja costera de Málaga durante el Pleistoceno Superior. In: Sanchidrián, J.L., Baldomero, A., Alcantara, M.M., Fullola, J.M. (Eds), La cuenca mediterránea durante el Paleolítico Superior (38.000-10.000), 326-341. Fundación Cueva de Nerja.

Cortés, M., Jiménez, F.J., Simón, M.D., López, J.A., Riquelme, J.A., Fernández, E., Martínez, F., Prats, E., Arroyo, E., Pérez-Pérez, A., Turbón, D., López, L., Pérez, S., 2008. La investigación sobre El Pirulejo. Una aproximación interdisciplinar. In Cortés (Ed): Cazadores-recolectores del Paleolítico superior en la sierra Subbética. Estudios en homenaje a la profesora María Dolores Asquerino. Antiqvitas 20, 213-222.

Cortés, M., 2003. Del Magdaleniense al Neolítico en la costa de Málaga. Novedades y perspectivas. In: Actas de las Jornadas temáticas andaluzas de Arqueología. Sociedades recolectoras y primeros productores, 109-122. Junta de Andalucía, Sevilla.

Cortés, M., 2002. El Paleolítico superior final en el sur de la Península Ibérica: los yacimientos de la provincia de Málaga. Mainake XXIV, 279- 300.

Coûteaux, M., 1977. A propos de l'ínterpretation des analyses polliniques de sediments minéraux principalement archeologiques on le milieu végétal, les faunes et l'homme. In : Laville, H., Renault-Miskovsky, J. (Eds.), Approche écologique de l'homme fossile, 259-276. Supplément du Bulletin de l'Association française pour Etude du Quaternaire 47.

Fernández, S., Fuentes, N., Carrión, J.S., González-Sampériz, P., Montoya, E., Gil-Romera, G., Vega-Toscano, G., Riquelme, J.A. 2007. The Holocene and Upper Pleistocene pollen sequence of Carihuela Cave, southern Spain. Geobios 40, 75-90.

Fortea, J., 1973. Los complejos microlaminares y geométricos del Epipaleolítico Mediterráneo Español. Universidad de Salamanca.

Fullola, J.M., Villaverde, V., Sanchidrián, J.L., Aura, E., Fortea, J., Soler, N., 2006. El Paleolítico Superior Mediterráneo Ibérica. In J. L. Sanchidrián et al. (Eds.), IV Simposio de Prehistoria Cueva de Nerja. La Cuenca Mediterránea durante el Paleolítico superior. 38.000-10.000 años, 192-211. Fundación Cueva de Nerja.

García-Franco, A., Morgado, A., 2018. Análisis de los métodos de talla de núcleos del Tajo de Marchales (Granada), un yacimiento del Magdaleniense mediterráneo. CPAG 28, 213-231.

Gárate, D., García, A., 2011. Revisión crítica y contextualización espacio-temporal del arte parietal paleolítico de la Cueva de El Niño (Ayna, Albacete). Zephyrus, LXVIII, 15-39.

Giles, F., Finlayson, C., Gutiérrez, J.M., Santiago, A., Finlayson, G., Reinoso, C., Giles, F., 2001. Investigaciones arqueológicas en Gorham's cave (Gibraltar). Resultados preliminares de las campañas de 1977 a 1999. Almoraima 25, 49-64.

Girard, M., Renault-Miskovsky, J., 1969. Nouvelles techniques de préparation en palynologie appliqués à trois sédiments du Quaternaire final de l'Abri Cornille (Istres, Bouches du Rhône). Bulletin del'Association française pour l'Etude du Quaternaire 4, 275-284.
González-Sampériz, P., Leroy, S.A.G., Carrión, J.S., Fernández, S., García-Antón, M., Gil-García, M.J., Uzquiano, P., Valero-Garcés, B., Figueiral, I., 2010. Steppes, savannahs, forests and phytodiversity reservoirs during the Pleistocene in the lberian Peninsula. Review of Palaeobotany and Palynology 162(3), 427-457.

Goeury, C., De Beaulieu, J.L., 1979. A propos de la concentration du pollen a l'aide de la liqueur de Thoulet dans les sediments mineraux. Pollen et Spores XXI (1-2), 239-251.

González Ríos, M.J., 2016. La Cueva de Malalmuerzo y otras cavidades de: Campotejar, Colomera, Iznalloz, Moclín y Montillana (Granada). Granada Subterránea IX. Grupo de Espeleólogos Granadinos, Diputación de Granada.

Graziosi, P., 1974. L'Art Paleolithique de la province mediterranéen et ses influences dans les temps post-paleolitiques. Werner Gren Foundation for Antropology, New York.

Grimm, E.C., 1987. CONISS: a FORTRAN 77 program for stratigraphically constrained cluster analysis by the method of incremental sum of squares. Computers Geosciences 13, 13-35.

Grimm, E.C., 2004. TGView. Springfield: Illinois State Museum, Research and Collection Center. Illinois.

Jiménez S.A., Ortega, J.A., García, M., 1986. Incisiones intencionales sobre huesos humanos del Neolítico de la Cueva de Malalmuerzo (Moclín, Granada). Antropología y Paleoecología Humana 4, 34-65.

Laplace, G., 1972. La typology analytique et structurale: Base rationnelle d'étude des industries lithiques et osseuses. Colloques Nationaux C.N.R.S. n 932. Banques des Donnés Archéologiques, 91-143. París.

López Sáez, J.A., Van Geel, B., Martín, M., 2000. Aplicación de los microfósiles no polínicos en Palinología Arqueológica. In Oliveira Jorge, V. (Coord. Ed.), Contributos das Ciências e das Technologias para a Arqueologia da Península Ibérica. Actas $3^{\circ}$ Congresso de Arqueologia Peninsular, vol. IX, Vila-Real, Portugal, 11-20. Adecap, Porto.

Ludwig, P., Shao, Y., Kehl, M., Weniger, G.-C., 2018. The Last Glacial Maximum and Heinrich event I on the Iberian Peninsula: A regional climate modelling study for understanding human settlement patterns. Global and Planetary Change 140, 34-47.

Martin Lerma, I., 2015. Funcionalidad de la industria lítica Magdaleniense del interior peninsular: La Peña de Estebanvela (Ayllón, Segovia). Tesis Doctoral Uned. Madrid.

Navarro, C., Carrión, J.S., Munuera, M., Prieto, A.R., 2001. Sedimentación y distribución superficial de palinomorfos en cuevas del SE Ibérico. Implicaciones en Paleoecología. Anales de Biología 23, 102-132.

Pericot, L., 1942. La cueva de Parpalló (Gandía). C.S.I.C. Instituto Diego Velázquez, Madrid.

Ramos, J., Cortés, C., Aguilera, A., Lozano, M.C., Vera, J.L., Simón, M.D., 2005. El Magdaleniense y Epipaleolítico del Complejo del Humo (La Araña, Málaga). In: Sanchidrián, J. L., Márquez, A.M., Fullola, J.M. (Eds.), IV Simposio de Prehistoria Cueva de Nerja. La Cuenca mediterránea durante el Paleolítico Superior 38.000-10.000. Reunión de la VIII Comisión de la UISPP, 326-341. Fundación Cueva de Nerja, Málaga.

Ripoll, S., Muñoz, F.J., 2019. Paleolithic rock art from la cueva de Ambrosio (Almería, Spain): Revisited twenty-five years later. In: Schmidt, I., Cascalheira, J., Bicho, N., Weniger, G. (Eds), Human Adaptations to the Last Glacial Maximum: The Solutrean and its Neighbors, 433-452. University of Cologne, University of Bonn and RWTH Aachen University. 
Riquelme, J.A., 2002. Cueva de las Ventanas. Historia y Arqueología. Ayuntamiento de Piñar, Granada.

Sánchez, S., 2004. Las industrias líticas de la cueva de las Ventanas de Piñar (Granada) desde el Paleolítico superior a la edad del Cobre. Arqueología y Territorio 1, 1-13.

Sanchidrián, J.L., Medina, M.A., Liñan, C., del Rosal, Y., Cóbos, J. M., Ruíz, R. M., Torres, A., 2017. Regreso a la cueva de El Morrón (Torres, Jaén): revisión arqueológica treinta y cinco años después de su descubrimiento. Munibe Antropologia-Arkeologia 68, 85-100.

Sanchidrián, J.L., Márquez, A.M., 2003. Dataciones y sus repercusiones en el arte prehistórico malagueño. Mainake XXV, 275- 292

Sanchidrián, J.L., 1982. Cueva Navarro (Cala del Moral) Málaga. Corpus Artis Rupestris. I. Palaeolothica Ars. Vol I. Salamanca.

Schmidt, I., Bradtmöller, M., Kehl, M., Pastoors, A., Tafelmaier, Y., Weninger, B., Weniger, G-C., 2012. Rapid climate change and variability of settlement patterns in Iberia during the Late Pleistocene. Quaternary International 274, 179-204.

Simón, M.D., Navarrete, I., Cortés, M., Lozano, M.C., Vera, J.L., 2006. Nuevos elementos simbólicos sobre soporte malacológico del Paleolítico Superior de la provincia de Málaga (Andalucía, España). In Sanchidrián, J.L., Márquez, A.M. y Fullola, J.M. (Eds.), IV Simposio de Prehistoria Cueva de Nerja. La Cuenca mediterránea durante el Paleolítico Superior 38.000-10.000. Reunión de la VIII Comisión de la UISPP, 366-378. Fundación Cueva de Nerja, Málaga.

Solari, A., Botella, M., Alemán, I., 2012. Canibalismo en la Cueva de Malalmuerzo. BAR International Series 2418.
Straus, L.G., 2012. El Solutrense: 40 años de reflexiones por un arqueólogo norteamericano. Espacio, Tiempo y Forma Serie I, Nueva época Prehistoria y Arqueología 5, 27-36.

Straus, L.G., 2018. The Upper Paleolithic of Iberia. Trabajos de Prehistoria 75(1), 9-51.

Toro, I., Almohalla, M., 1979. Industrias del Paleolítico Superior en la provincia de Granada. C.P.U.G 4, 1-20.

Toro, I., Almohalla, M., Argamasilla, M., 1980. Nuevas aportaciones al conocimiento de las industrias del Paleolítico Superior en la provincia de Granada. C.P.U.G 5, 1-14.

Toro, I., Ramos, M., 1985. Excavaciones arqueológicas en el yacimiento Solutreogravetiense al aire libre del Pantano de Cubillas. Primeros resultados. C.P.U.G 10, 9-30.

Uzquiano, P., 1997. Antracología y métodos: implicaciones en la economía prehistórica: Etnoarqueología y Paleoecología. Trabajos de prehistoria 54(1), 145-154.

Van Geel, B., 1978. A palaeoecological study of Holocene peat bog sections in Germany and The Netherlands". Review of Palaeobotany and Palynology 25, 1-120.

Villaverde Bonilla, V., Román, D., Pérez Ripoll, M., Mercé Bergadà, M., Real, C., 2012. The end of the Upper Palaeolithic in the Mediterranean Basin of the Iberian Peninsula. Quaternary International 272-273, 17-32.

Weniger, G.-C., de Andrés-Herrero, M., Bolin,V., Kehl, M., Otto, T., Potì, A., Tafelmaier, Y., 2019. Late Glacial rapid climate change and human response in the Westernmost Mediterranean (Iberia and Morocco). PLoSONE 14(12):e0225049. https://doi.org/10.1371/journal.pone.0225049. 
